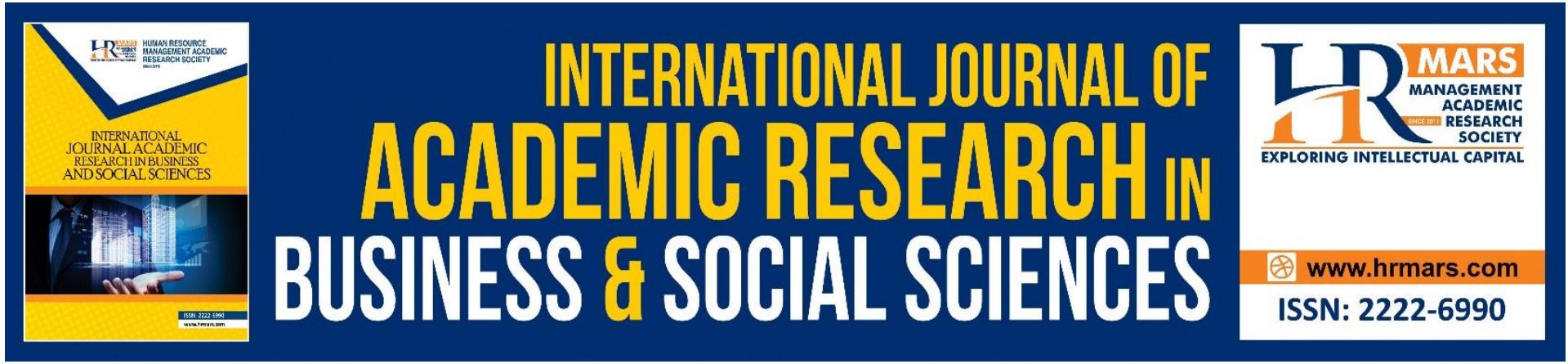

\title{
Effects of Internal Marketing on Job Satisfaction Among Islamic Bank Employees in Sabah: A Review Paper
}

Nur Azwanie binti Mohd Nasrie, Dewi Tajuddin, Hajjah Hasnawati Hj Guliling

To Link this Article: http://dx.doi.org/10.6007/IJARBSS/v11-i7/10570

DOI:10.6007/IJARBSS/v11-i7/10570

Received: 21 May 2021, Revised: 24 June 2021, Accepted: 09 July 2021

Published Online: 28 July 2021

In-Text Citation: (Nasrie et al., 2021)

To Cite this Article: Nasrie, N. A. binti M., Tajuddin, D., \& Guliling, H. H. H. (2021). Effects of Internal Marketing on Job Satisfaction Among Islamic Bank Employees in Sabah: A Review Paper. International Journal of Academic Research in Business and Social Sciences, 11(7), 1016-1022.

Copyright: (c) 2021 The Author(s)

Published by Human Resource Management Academic Research Society (www.hrmars.com)

This article is published under the Creative Commons Attribution (CC BY 4.0) license. Anyone may reproduce, distribute, translate and create derivative works of this article (for both commercial and non-commercial purposes), subject to full attribution to the original publication and authors. The full terms of this license may be seen at: http://creativecommons.org/licences/by/4.0/legalcode

Vol. 11, No. 7, 2021, Pg. 1016 - 1022

http://hrmars.com/index.php/pages/detail/IJARBSS

JOURNAL HOMEPAGE

Full Terms \& Conditions of access and use can be found at http://hrmars.com/index.php/pages/detail/publication-ethics 


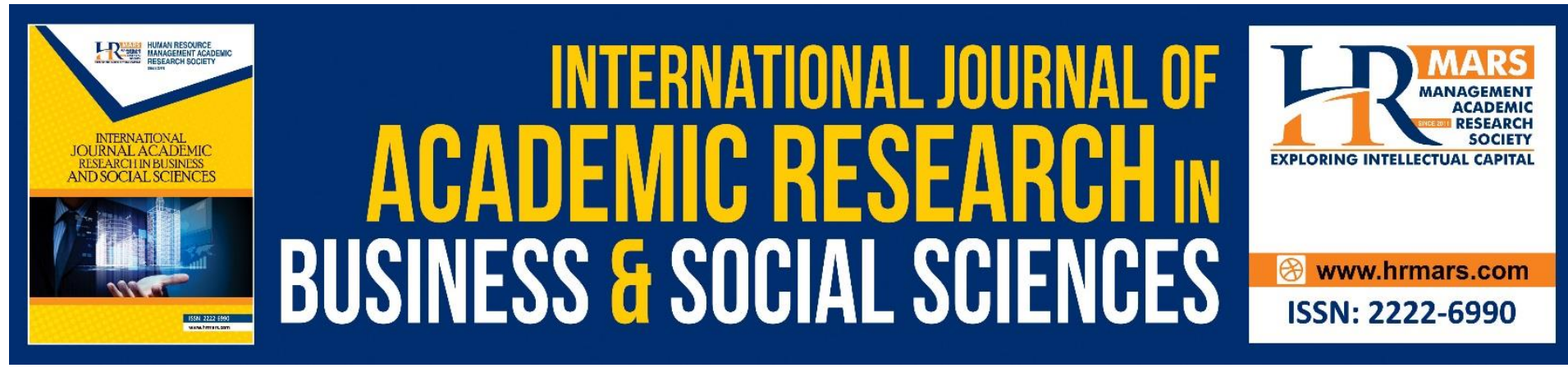

\title{
Effects of Internal Marketing on Job Satisfaction Among Islamic Bank Employees in Sabah: A Review Paper
}

\author{
Nur Azwanie binti Mohd Nasrie, Dr Dewi Tajuddin, Dr Hajjah \\ Hasnawati Hj Guliling \\ Faculty of Business Management, Universiti Teknologi MARA (UiTM), Cawangan Kota \\ Kinabalu, Sabah.
}

\begin{abstract}
Malaysia is still considered the leader and cranium of Islamic banking; despite numerous challenges, it has succeeded in creating a full-fledged Islamic banking system parallel to the existing conventional system. Islamic banking issues of not having sufficient training and career development for their employees had led to serious issues, and it is the manager's responsibility to curb these issues. Thus, this paper aims to verify the relationship between internal marketing and job satisfaction in Islamic banks in Sabah. Three dimensions of internal marketing are considered: training, career development, and leadership. The paper adopts a quantitative, descriptive, and correlational study using a cross-sectional survey design of a cross-sectional research methodology. Data are collected through an online questionnaire involving 200 bank employees. Statistical Package for Social Scientist and Partial least squares-structural equation modeling is used to verify the predicted relationships.
\end{abstract}

\section{Introduction}

Malaysia's financial services industry has an increasing turnover rate from $7.4 \%$ in 2012 to 13.3\% in 2013 (Willis Towers Watson, 2013). The financial and banking sector is found to have the highest turnover rate, with $18.3 \%$ (Letchumanan, Apadore \& Ramasamy, 2017). The turnover rate will increase if employees are dissatisfied; thus, it will negatively impact organizational effectiveness (Adigwe \& Oriola, 2015). Employee turnover is a complex business problem that entails business leaders' participation; losing well-trained workers negatively affects profitability, productivity, and administrative sustainability (Jehanzeb, Hamid, \& Rasheed, 2015). The drops in productivity and profitability are due to employees' job dissatisfaction (Usman et al., 2015).

Currently, Malaysia's Islamic finance talents do not have formal Islamic finance qualifications. This is supported by Hassan, Albasri, Rusli, \& Ahmad (2018) whereby professional bankers with a background in modern economics or conventional law lack Islamic economics principles on how Islamic banks operate. Finance Accreditation Agency (FAA), in cooperation with the Islamic Finance News (IFN), revealed that Islamic finance practitioners require more training and skill development (Ali, 2017). Moreover, there is limited 
opportunity for professional training in Sabah to enhance Islamic banking skills among bank employees (Amir, The Borneo Post, 2016).

Therefore, successfully implemented internal marketing activities have many important benefits and consequences for individuals and organizations (Dunne \& Barnes, 2000: 196). The implied assumption is that satisfied employees will perform their jobs better, which positively impacts customer satisfaction (Berry, 1981; Chi et al., 2016). In turn, satisfied internal customers will be faithful and unlikely to change their jobs resulting in a lower turnover.

\section{Literature Review Internal Marketing}

Internal marketing has been defined as an effort to make available internal products (jobs) that satisfy the needs of an important internal market (employees) while satisfying the firm's objectives (Berry et al., 1976, p. 8; Berry \& Parasuraman, 1991). A study conducted by Shahzad and Naemm (2013) showed that internal marketing is positively related to job satisfaction. Findings from past research concluded that applying internal marketing can help employees achieve external customer satisfaction because employee satisfaction is within the internal marketing scope and also externally oriented (Gounaris et al., 2010). Thus, internal marketing is not only related to motivation and satisfaction but also scope and practice. It has been confirmed, either conceptually and empirically, that there is a positive relationship between internal marketing and job satisfaction (Chang \& Chang, 2007; Ro \& Chen, 2011; Back et al., 2011).

\section{Training - Internal Marketing Indicator/Dimensions}

According to Jabbour (2013), training is "a systematic organizational process that gives employees the knowledge, attitudes, and skills to help organizations implement their missions and visions." Thus, based on the definition by Jabbour (2013); Dusuki and Abdullah (2007); Dusuki and Irwani (2008), training can give employees knowledge, attitudes, and skills according to Islamic beliefs, namely Shari'ah. The term Shari'ah can be defined as "a system of ethics and values covering all features of life including personal, social, political, economics and intellectual with rigid attitudes, as well as major means of adjusting to change as inseparable from Islamic beliefs, values and objectives" (Dusuki \& Abdullah, 2007; Dusuki \& Irwani, 2008).

A study by Siddiqui and Usmani (2014) stated that it is compulsory for Islamic banking and finance sector to fulfill and accomplish all the requirements of Shari'ah, in terms of their business operations and employer-employee and organization relationships. In order to achieve better Shari'ah compliance, which will significantly reflect their career developments, it is suggested that Shari'ah training should be given to employees (Shafii et al., 2013). For smooth and professional Islamic banking operations, it is crucial to have a properly skilled human resource. As a result, trained employees can maintain their relationships with customers as they are trained and responsible to make a big impact through increasing company efficiency. A study by Persaud (2010) concluded that training plays a vital role in employees' satisfaction and reduces turnover intention drastically.

\section{Career Development - Internal Marketing Indicator/Dimension}

Missbach (2015) indicated that career development is an instrument that could accommodate the information needs of career opportunities for organizational members. It 
can help employees to get clear career direction, define their career goals, find out the requirements of their target position, and motivate them to do the needful. Past literature suggested that employees will be satisfied when there is a good career development system, and the company designs the system for managerial and professional staffs (McCracken, 2002; Rutherford, 2005).

Consequently, it is vital to ensure employees' job satisfaction to be a successful organization, as employees' satisfaction is not only about their financial needs. Additionally, their sense of fulfilment gives them great meaning. Thus, organizations need to invest in their employees' well-being and career development. Research by Choo and Bowley (2007) also recommended that training and development programs influence job satisfaction which, in turn, would retain employees of the organization.

\section{Leadership - Internal Marketing Indicator/ Dimensions}

Fitzgerald and Schutte (2010) stated that leaders from transformational perspective should motivate and inspire employees towards their visions, understand employees' needs, and help employees to reach their potential; all of which give the best outcomes for the organization. Transformational leadership is about the relationship between leaders and followers aimed at elevating the value and motivation of their followers to a higher level. Previous studies stated that employees working with a transformational leader have greater satisfaction, feel more identification with both their leader and jobs and have strong motivation to show greater performance (Bass \& Bass, 2008).

\section{Job Satisfaction - Dependent Variable}

Job satisfaction refers to a particular employee's perception and evaluation of work based on his/her needs, values, and expectations. It is defined by Porter (1962) (as cited in Rayton \& Yalabik, 2014) as the degree to which employee perceives job needs as being fulfilled. According to Davidman (2004), 'motivation' views individuals' commitment towards work and workplace originated from within themselves, from the point of view of individual needs, likes, and preferences.

Based on Herzberg's concept, motivation factors, or motivators, are intrinsic to the job and lead to positive behavior towards work since they satisfy the 'need for growth or selfactualization' (Herzberg, 1966, p.75). Motivation aspects are correlated to a person's job satisfaction and include advancement, the work itself, possibility of growth, responsibility, acknowledgement, and attainment (Herzberg, 1966). Intrinsic motivation is a basic feature of a person who is mindful towards employee participation in work responsibilities; some worker takes part beyond the task interest. Intrinsic motivation is the result of the individuals or the activity itself (Skinner, 1953), which impacts the performance, attitude, and worker's well-being, directly and positively. Thus, intrinsic motivation is developed within the person without any concern or reassurance from others but purely based on their readiness.

\section{Research Framework}

Figure 1 illustrates the relationship and effects of internal marketing on job satisfaction. This model has been taken to be used as a vehicle for the research framework of the current study. 


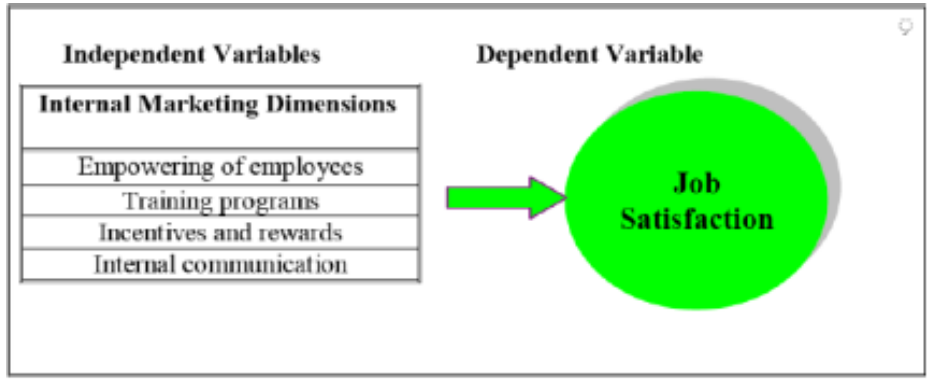

Figure 1: Adopted from Al-Khasawneh, Yahya (2016). Impact of Application of the Internal Marketing on Job Satisfaction for the Employees in the Islamic Banks a Case Study of Jordan

\section{Conceptual Framework}

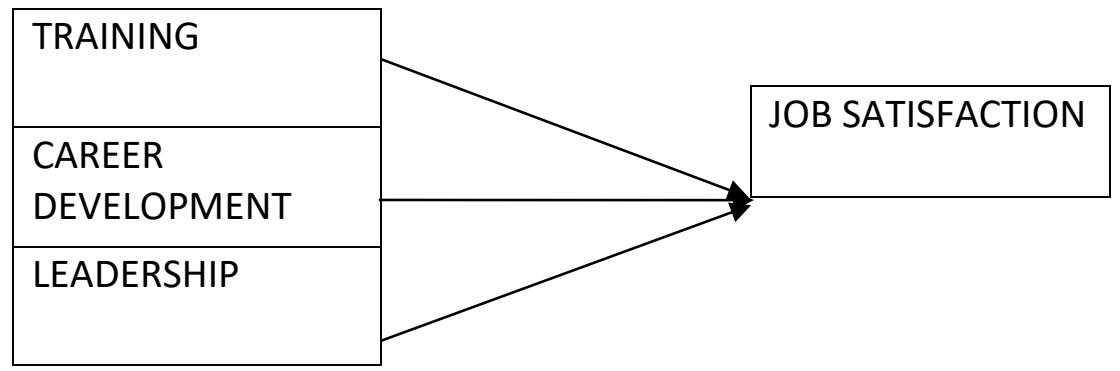

\section{Hypothesis}

Based on the theoretical and conceptual framework provided, this study develops the following hypotheses.

$\mathrm{H}$ : To determine the relationship between internal marketing and job satisfaction

$\mathrm{H}_{1}$ : To determine the relationship between training and job satisfaction

$\mathrm{H}_{2}$ : To determine the relationship between leadership and job satisfaction

$\mathrm{H}_{3}$ : To determine the relationship between career development and job satisfaction

$\mathrm{H}_{4}$ : To validate the proposed research model

\section{Research Method}

The researcher chose the quantitative research technique for this research. Research design for this study is a correlational study using a cross-sectional survey design seeking to test the relationship between independent variables (training, and leadership, career development), dependent variable (job satisfaction). Data that collected are the primary sources. The primary data would be collected from through the distributed questionnaire. The entire online sources of data collection are preferred accordingly to analysis from various references and their reliability check (Kaur, 2013).

The target population of this study consists of female and male employees from Islamic banks' employees from different departments and levels, including officers, executives, and managers of the management and operational level of two (2) Islamic banks (Bank Islam and Bank Muamalat) located in Kota Kinabalu, Sandakan, and Lahad Datu. This study depends on the primary sources of data gathered from respondents by filling in the distributed questionnaires. The sample size is estimated around 200 of the whole employees of Islamic banks (Bank Islam and Bank Muamalat). The researcher uses the recommendation by Hair et al. (2010), whereby he suggests the minimum sample size is 100 when considering models containing five or fewer constructs. Each construct has more than three (3) items. As indicated by $\mathrm{G}$ Power 3.1.9.4. calculation, the minimum sample for this study is 153 respondents (f $2=$ 
0.15 , the number of predictors $=7)$. Thus, this study will apply G Power 3.1.9.4 to adopt the recommended number of the targeted population.

In this study, purposive sampling technique under non-probability sampling is used in this research, which refers to the way a sample is selected; each respondent (employees of the organization) will be sent an internet-based survey through email. The full-fledge Islamic banks in Sabah according to the district which is Bank Islam in Kota Kinabalu, Keningau, Tawau, Lahad Datu, Sandakan, Alamesra and Bank Muamalat in Kota Kinabalu, Tawau, Sandakan.

\section{Conclusion}

This study may likewise prompt improvement in business activity in light of the fact that satisfied employees convey better services to the customers and help to maximize productivity and profit (Salleh, Sulaiman, Mohamad, \& Sern, 2015). Apart from that, if the business activity improved, hence the community or customer will be satisfied as well.

Additionally, the significance of this study employee job satisfaction effects and promotes employee wellbeing (Basri, Rashid, Abashah, \& Samah, 2017; Javed, 2014). Internal marketing is created to enhance company employee-bonds (Peltier et al., 2013). Das (2003) suggested that human resource management must concentrate on the employee engagement; if the employees are engaged then they will represent their organization positively. Hence, it will create positive internal marketing. The results of this study may help the bank leaders to improve employee job satisfaction, increase profitability and promote employee wellness.

The research work broadens the knowledge of the researcher. The findings of this study would also contribute to knowledge and literature about internal marketing and possibly provide management with valuable information on how to use internal marketing to achieve corporate objectives. This study may add to positive social changes by including information about the general study of job satisfaction, which could help diminished employee job satisfaction in different industries (Orumwense, 2018).

\section{References}

Adigwe, I., \& Oriola, J. (2015). Towards an understanding of job satisfaction as it correlates with organizational change among personnel in computer-based special libraries in Southwest Nigeria. The Electronic Library.

Al-Khasawneh, Y., (2016). Impact of Application of the Internal Marketing on Job Satisfaction for the Employees in the Islamic Banks a Case Study of Jordan

Amin, H. (2016). Challenges facing the Islamic banking industry in Sabah, Sarawak. The Borneo Post (Sabah, p. a16.)

Basri, H. H., Abd Rashid, I. M., Abashah, A. B., \& Samah, I. H. A. (2017). The impact of Malay transactional leadership style on employee performance; The Malaysia'pharmacy industry perspective. International Journal of Information, Business and Management, 9(2), 45.

Berry, L. L. (1981). The employee as customer. Journal of Retail Banking, 3(1), 33-40.

Berry, L., and Parasuranam, A. (1991), Competing Through Quality, Free Press, New York.

Chi, H., Yeh, H., Liou, J. (2016). " How Internal Marketing Mediates the Relationship between Teacher's Organizational Commitment and Job satisfaction". Journal of Education \& social policy. 3(1):56-69. 
Choo, S., \& Bowley, C. (2007). Using job training and development to affect job satisfaction within franchising. Journal of Small Business and Enterprise Development, 14(2), 339352.

Dusuki, A. W., \& Abdullah, N. I. (2007). Maqasid al-shari'ah, maslahah and corporate social responsibility. The American Jornal of Islamic Social Sciences, 24(1), 25-45

Fitzgerald, S., \& Schutte, N. S. (2010). increasing transformational leadership through enhancing self-efficacy. Journal of Management Development, 29(5), 495-505. https://doi.org/10.1108/02621711011039240

Gounaris, S. (2008). The notion of internal market orientation and employee job satisfaction : some preliminary evidence. 1(June 2006), 68-90. https://doi.org/10.1108/08876040810851978

Hassan, N. S. A., Albasri, S. H., Rusli, R. Z. A., \& Ahmad, R. (2018). Exploring the Impact of Shariah Training for Professional Bankers in Malaysia.

Herzberg, F. (1965). The motivation to work among finish supervisor.Personal psychology, 18(4) 393-402.

Jabbour, C. J. C. (2013). Environmental training in organizations: From a literature review to a framework for future research. Resources, Conservation and Recycling, 74, 144-155.

Jehanzeb, K., Hamid, A. B. A., \& Rasheed, A. (2015). What is the role of training and job satisfaction on turnover intentions?. International Business Research, 8(3), 208

Kaur, D., Sambasivan, M., \& Kumar, N. (2013). Effect of spiritual intelligence, emotional intelligence, psychological ownership and burnout on caring behaviour of nurses: $A$ cross-sectional study. Journal of Clinical Nursing, 22(21-22), 3192-3202. http://doi.org/10.1111/jocn.12386

Letchumanan, T., Apadore, K., \& Ramasamy, M. (2017). Factors influence turnover intention in commercial banks Malaysia: A theoretical model. Innovative Journal of Business and Management, 6(3), 13-21.

Lindholm, R. (2013). Managing Retention by Engaging Employees in a Case Company.

Ali, M. (2017). Islamic finance calls for more talents. new straits times. https://www.nst.com.my/opinion/columnists/2017/11/306947/islamic-finance-callsmore-talents

Missbach, A. (2015). Making a" career" in people- smuggling in Indonesia: protracted transit, restricted mobility and the lack of legal work rights. Sojourn: Journal of Social Issues in Southeast Asia, 30(2), 423-454.

Shafii, Z., Salleh, S., Hanefah, M. H. M., \& Jusoff, K. (2013). Human capital development in Shariah audit. Middle East Journal

Shahzad, T., \& Naeem, H. (2013). Role of internal marketing in employee engagement leading to job satisfaction of employees in private banks of Pakistan. IOSR Journal of Business and Management, 8(2), 62-68.

Siddiqui, A. A., \& Usmani, O. (2014). Meezan Bank: A Role Model of Shariah Compliance for Islamic Banks. Journal of Islamic Banking \& Finance,

Usman, A. B., Afza, N., \& Amran, B. (2015). Corporate social responsibility practice and corporate financial performance: Evidence from Nigeria companies. Social Responsibility Journal, 11, 749-763. doi:10.1108/SRJ-04-2014-0050

Willis Towers Watson. (2013). Higher turnover rate in the Malaysian financial services industry, Towers Watson survey finds. TowersWatson.com, 2 October. Retrieved 5 December 2018 from https://www.towerswatson.com/en-MY/Press/2013/10/Higherturnover-rate-in-Malaysian-Financial-Services-industry. 